\title{
TASMIMOPANAS : Modified Paper Using Waste of Pineapple as Purifier of Waste Cooking Oil
}

\author{
D. P. Mardiana ${ }^{1}$, W. Pratiwi ${ }^{2}$, Z. Khamidah, ${ }^{3}$ and S.Alfarisi ${ }^{4}$ \\ ${ }^{1,2,3,4}$ Departement of Industrial Engineering, UniversitasMuria Kudus, Kudus, Indonesia \\ mardianadew@gmail.com
}

\begin{abstract}
Cooking oil was necessary of household to used when processed food ingridients. Waste cooking oil was contained free radicals can potentially oxidize organs. This problem overcome with rice straw and waste of pineapple which waste cooking oil was recycled by them. The utilization cellulose component on rice straw and waste of pineapple as natural active carbon can helped this problem. The absoption of subtances in waste cooking oil used paper from rice straw which heat together with $\mathrm{Na}_{2} \mathrm{SO}_{3}$ solvent while grinding processed with waste of pineapple to made pulp.
\end{abstract}

Keywords: waste of pineapple, cooking oil, pulp

\section{INTRODUCTION}

Cooking oil is a necessity of household which to use when process food ingredients. Cooking oil increases in term consumption and price that waste cooking oil increases (Ramdja et al, 2010). This problem can be overcome with rice straw and waste of pineapple which waste cooking oil is recycle by them. Rice straw is a biomass waste contains fiber and cellulose which is not use well (nasution, 2010). Besides, waste of pineapple also one of waste which contains fiber Larrauri et al, 1997.

Pineapple have consume directly and also to make a product in industry such as beverage products, pineapple syrup, foods that contain pineapple scents, and etc. The process to make product which produces waste. The utilization cellulose component on rice straw and waste of pineapple as natural active carbon can help this problem. The absoption of subtances in waste cooking oil is uses paper from rice straw which heat together with $\mathrm{Na}_{2} \mathrm{SO}_{3}$ solvent while grinding process with waste of pineapple to make pulp. It will be more beneficial for the community and can utilize rice straw and waste of pineapple to be more economical.

Waste cooking oil used in several time which repeatedly., that cooking oil was occured degradation reaction (Yustinah, 2011) therefore it was decreased the quality of cooking oil. Waste cooking oil has dark color, rancid smell, and triggered negative effect on body health (Pakpahan et al, 2013). Waste cooking oil was contained free radicals can potentially oxidize organs. The dark color of waste cooking oil caused by oxidative damage. The molecular bond between carbohydrates and molecules caused of dark color and thickens in cooking oil, the bond between these molecules was called the Maillard Reaction (Suroso, 2013). Waste cooking oil was contained carcinogenic substances that triggered cancer in the body (Pakpahan et al, 2013).

Rice straw was biomass waste which contained lignocellulosic fiber. Lignocellulosic contained fiber and lignin in ricestraw which has consisted carbohydrate polymers of cellulose and hemicellulose (Nasution, 2012). Cellulose was structural component of cell walls which possessed by green plants and it used in paper pulping (Lwako et al, 2013). The several methods used for paper pulp which included mechanical, heating, and chemical (Lwako et al, 2013). Chemical methods to made pulp included Kraft, sulfite, soda and organosolv(Lwako et al, 2013). See Table 1. This method used for reduced levels of lignin and hemicellulose whichcontained in plants. Cellulose contained in straw had hydroxyl group which reacted with reactive dyes which would be absorbed and dye cellulose fiber (Pakpahan et al, 2013). 
Table 1.

Chemical Methods For Pulping Commonly Used

\begin{tabular}{|c|c|c|c|}
\hline $\begin{array}{l}\text { Chemical } \\
\text { Pulping }\end{array}$ & $\begin{array}{c}\text { MethodsChemicals } \\
\text { Used }\end{array}$ & $\begin{array}{c}\text { Properties of Isolated } \\
\text { Pulp }\end{array}$ & $\begin{array}{c}\text { Common Uses of isolated } \\
\text { Pulp }\end{array}$ \\
\hline Sulphite & $\begin{array}{l}\text { Sulphurous acid/ sodium } \\
\text { sulphite }\end{array}$ & $\begin{array}{l}\text { High flexibility and } \\
\text { requires very little } \\
\text { bleaching }\end{array}$ & $\begin{array}{l}\text { Used in making paper for } \\
\text { special purposes }\end{array}$ \\
\hline Kraft/ Sulphate & $\begin{array}{l}\text { Combination sodium } \\
\text { hydroxideand sodium } \\
\text { sulphide }\end{array}$ & $\begin{array}{l}\text { Strong, low } \\
\text { brightness(dark brown) }\end{array}$ & $\begin{array}{l}\text { Making boxes, paper bags } \\
\text { and wrapping } \\
\text { paper. Can also be used for } \\
\text { writing paperand } \\
\text { paperboard when bleached }\end{array}$ \\
\hline Soda & $\begin{array}{l}\text { Sodium hydroxide and } \\
\text { anthraquinone }\end{array}$ & $\begin{array}{l}\text { Have properties similar to } \\
\text { those of sulphite. }\end{array}$ & Ideal for all paper uses \\
\hline Organosolv & $\begin{array}{l}\text { Organic solvents e.g } \\
\text { Ethanol }\end{array}$ & $\begin{array}{l}\text { Much of the properties } \\
\text { arestill being tested } \\
\text { and evaluated }\end{array}$ & $\begin{array}{l}\text { Preliminary results suggest } \\
\text { possible } \\
\text { application in all aspects of } \\
\text { paper uses. }\end{array}$ \\
\hline Biopulping & $\begin{array}{l}\text { Involves the use of } \\
\text { white } \\
\text { fungus K14 }\end{array}$ & $\begin{array}{l}\text { Increased tear index, low } \\
\text { kappa number } \\
\text { and other properties are } \\
\text { still underinvestigations }\end{array}$ & $\begin{array}{l}\text { Results suggests possible } \\
\text { uses in all aspectsof paper }\end{array}$ \\
\hline
\end{tabular}

Source: Lwako KOM, Joseph BK, dan Baptist KJ.

Pineapple is one of the tropical fruits that has fiber with antioxidant activity (AA) of $86.7 \%$. AA is a bioactive component found in dietary fiber (Larrauri et al, 1997) so that it can neutralize free radicals (Putra et al, 2013) Pineapple has the ability as a natural activated carbon which acts as an adsorbent to purify waste cooking oil. To remove impurities and toxic substances in used oil (Putra et al, 2013). With the advance of technology and science, the pineapple pulp can be used as waste cooking oil adsorbent. The composition contained in pineapple is listed in table 2 .

Table 2. Content of Pineapple (Source: FatSecret API Platform)

\begin{tabular}{lc}
\hline \multicolumn{2}{c}{$\begin{array}{c}\text { Nutritional information on pineapple } \\
\text { fruit per 100 gram }\end{array}$} \\
\hline Fat & $0,12 \mathrm{~g}$ \\
Saturated Fat & $0,009 \mathrm{~g}$ \\
Polyunsaturated Fat & $0,042 \mathrm{~g}$ \\
Single Saturated Fat & $0,014 \mathrm{~g}$ \\
Cholestrol & $0 \mathrm{~g}$ \\
Protein & $0,54 \mathrm{~g}$ \\
Carbohydrate & $12,63 \mathrm{~g}$ \\
Fiber & $1,4 \mathrm{~g}$ \\
Sugar & $9,26 \mathrm{~g}$ \\
\hline
\end{tabular}




\section{Tibuana}

Journal of applied Industrial Engineering-University of PGRI AdiBuana

$p$-ISSN 2622-2027

$e$-ISSN 2622-2035

\section{RESEARCH METHODOLOGY}

\section{A. Case Study}

The problem of waste cooking oil usually found in both households and indutries that use cooking oil as the process of making a product. Waste cooking oil disposed without treatment so that can cause of environment problem (waste) and cause cost inefficiency. This problem is the basis of this study to be able to reduce environmental waste and improve the cost efficiency for housewives and industry players.

\section{B. Materials and Tools}

The materials and tools used to make Tasmimopanas: modified paper using waste pineapple are chemical electric stove with magnetic stirter, oven, Chemical measuring cup, beaker glass, blender, Traditional screen printing, sodium sulfite, waste of cooking oil, aquades, strach flour, rice straw, waste ofpineapple.

\section{Made Straw Paper Pulp}

In this step, 50 grams of rice straw cut into small pieces with a size of approximately $1 \mathrm{~cm}$ (Figure 1), Then, 4 gram of sodium sulfite prepared in beaker glass with water. And, rice straw put in beaker glass where sodium solvent had prepared. They were heated by chemical electric stove with magnetic stirter for an hour at temperature $160^{\circ} \mathrm{C}$ (Figure 2). After that, rice straw washed with aquades (Figure 3) before blent rice straw mechanically by blender. Then, Rice straw was refined by blender (Figure 1).

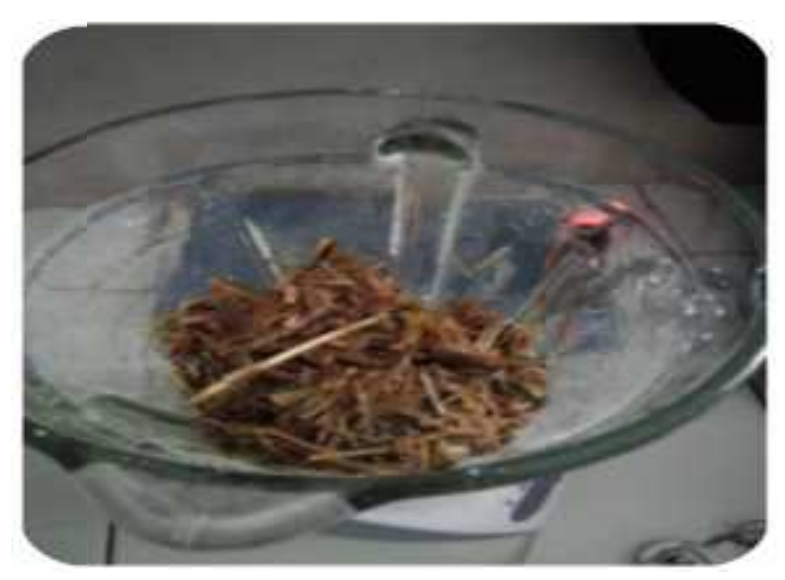

Figure 1. refine rice straw with a blender

\section{Made Natural Active Carbon}

Natural Active Carbon from Waste of Pineapple was makedby followed this step (Figure 6):

- Drying: 0,5 kg waste of pineapple had washed before oven dried with temperature $160^{\circ} \mathrm{C}$ for 60 minutes to form carbon or dried.

- Refining: The carbon-shaped from waste of pineapple refined by blender until it was become powder (Figure 2).

\section{E. ModifiedPulp Paper}

On this step, straw paper pulp and powdershaped natural active carbon from waste of pineapple was modified by blender after strach flour had put with ratio 1:1. After they mixed it, the pulp molded by Traditional screen printing. 


\section{Tibuana}

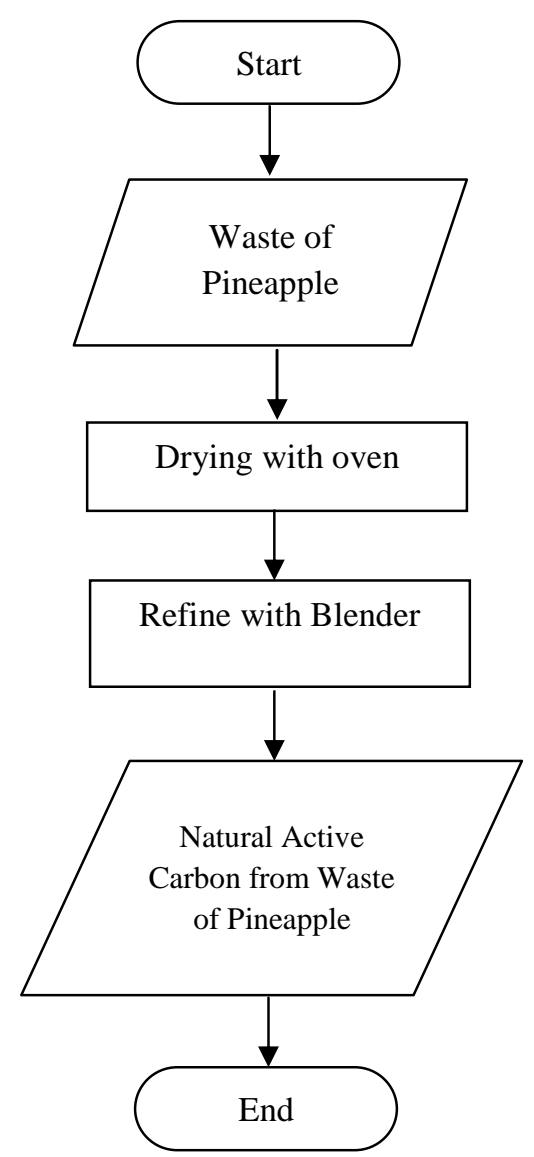

Figure 2. Natural Active Carbon making process

\section{RESULT AND DISCUSSION}

This study had result natural actived carbon from waste of pineapple. We used waste of pineapple because it potentially. The pineapple was contained antioxidant activity (AA) of $86.7 \%$ and 12,36 gram carbohydrate. Which the result of Powder-shaped Natural ActiveCarbon from waste of pineapple (Figure
3). The Chemical method with Sodium Sulfite $\left(\mathrm{Na}_{2} \mathrm{SO}_{3}\right)$ used for modified paper which this method was reduce leveled of lignin in rice straw and sulfite method used for special purposed. This method did rice straw put in beaker glass where sodium solvent had prepared. They were heated by chemical electric stove with magnetic stirter for an hour.

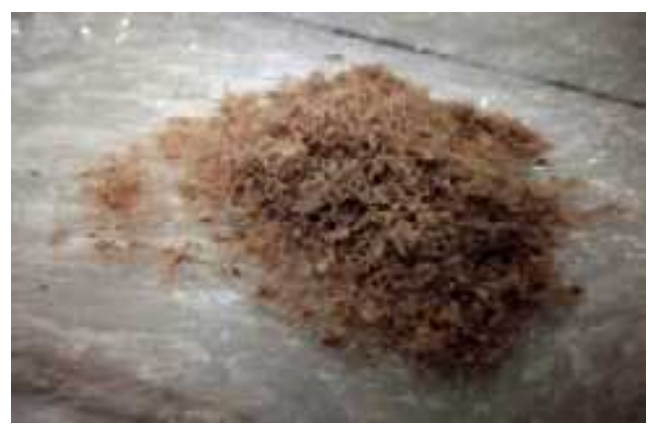

Figure 3.Powder-shaped Natural ActiveCarbon from waste of pineapple 


\section{Tibuana}

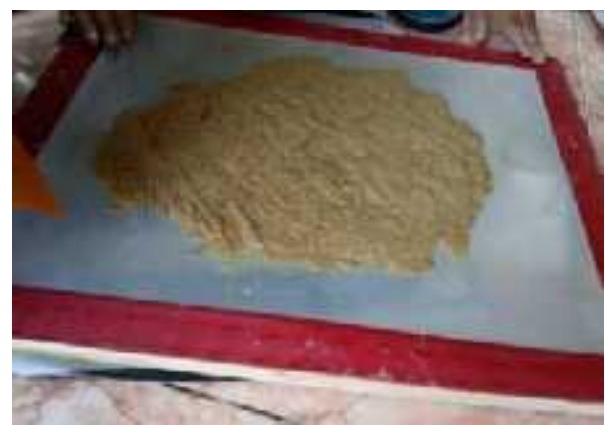

Figure 4. The Pulp molds by Traditional screen printing

So that, this method has affected for pulp of tasmimopanas: modified paper used waste of pineapple produced (Figure 4). If the heating process has been carried out, Rice straw washed with aquades.Then, rice straw refined mechanically before it was molded by traditional screen printing (Figure 9). After that, the waste cooking oil filtered used with tasmimopanas. The result obtained was deficient, because the leveled permeability and thickness of paper was deficient that needed considerable time. But, the the waste cooking oil filtered has result changed dark color be more brighter. And the quality and hygiene testing shall do it for next study

\section{CONClusion}

The result of this study is being deficient because the level of permeability and thickness of paper. It is cased time consuming for filtering process. However, the waste cooking oil filtered by this modified paper show the change on color. The dark cark color has been more brighter. The quality and hygiene testing will be conducted on next study.

\section{REFERENCES}

1. A.F. Ramdja, L. Febrina, D. Krisdianto. 2010. Pemurnian minyak jelantah menggunakan ampas tebu sebagai adsorben. Jurnal Teknik Kimia 1(17):7-14

2. Z.A. Nasution. 2010. Pembuatan dan karakterisasi kertas dari limbah jerami padi untuk tatakan gelas cetak tangan. Berita Selulosa (45(1):16-21
3. J.A. Larrauri, P. Ruperez, \&S.F. Calixto. 1997. Pineapple shell as source of sietary siber with associated polyphenols. J. Agric. Food Chem. 45:4028-4031

4. H. Yustinah. 2011. Adsorbsi minyak goreng bekas menggunakan arang aktif dari sabut kelapa. Prosiding Seminar Nasional Teknik Kimi "Kejuangan" B05-1-5

5. J.F. Pakpahan, T. Tambunan, A. Harimby, dan Y. M. Ritonga. 2013. Pengurangan FFA dan warna dari minyakjelantahdenganadsorbenserab utkelapa dan jerami. Jurnal Teknik Kimia USU, Article in press 2013.

6. A.S. Suroso. 2013. Kualitas minyak goreng habis pakai ditinjau dari bilangan peroksida, bilangan asam dan kadar air. Jurnal Kefarmasian Indonesia 3(2): 77-88

7. K.O.M. Lwako, B.K. Joseph, dan K.J. Baptist. 2013. A review on pulp manufacture from non wood plant materials. International Journal of Chemical Engineering and Applications 4(3):144-148W.-K. Chen, Linear Networks and Systems (Book style). Belmont, CA: Wadsworth, 1993, pp. 123-135.

8. A.Putra, S. Mahrdania, A. Dewi, and Saptia E.2012. Recovery minyak jelantah menggunakan mengkudu sebagai absorben. Prosiding Seminar Nasional PERTETA EAT-03:585589 